\title{
Intergovernmental Relations, Legitimacy, and the Atlantic Accords
}

\section{Jennifer Smith*}

\section{Introduction}

Are the Atlantic Accords regarded as legitimate agreements in Canada? If not, why not? And does it matter? The purpose of this article is to answer these questions.

Legitimacy resides in the eyes of the beholder. Who is the beholder? Initially, one thinks mainly of citizens in this respect. However, another beholder is government - other governments. In federations, governments often deal directly with one another, a sphere of activity called executive federalism. When the central government negotiates agreements with one or more (but not all) regional governments, the rest are relegated to the status of observers. As observers, they might well have ideas on the legitimacy of the activity, including the process used and the resulting agreement that is reached.

In this article I propose to examine the legitimacy of the Atlantic Accords from the standpoint of citizens and other governments. The accords are agreements reached between the federal government and Newfoundland and Labrador (NL) in 1985, ${ }^{1}$ and the federal government and Nova Scotia (NS) in $1986 .{ }^{2}$ In 2005, supplementary agreements were reached on the relationship between the accords and equalization payments. In 2007, further adjustments of that relationship were made for NS.

In the first section of the article, there is a discussion of legitimacy in connection with the practice of executive federalism. It is followed in the next section by an account of the establishment of the accords. In the third section there is an analysis of the renegotiation of the accords that took place between the federal government and each of the two provinces in 2004-7 - twice. In the conclusion, the questions about legitimacy posed at the outset of the article are addressed.

\section{Executive Federalism and Legitimacy}

Canadian political scientist Donald Smiley devised the phrase executive federalism to describe the "relations between elected and appointed officials of the two orders of government in federal-provincial interactions and among the executives of the provinces in interprovincial interactions." 3 By government, he meant the elected representatives in the legislature who are also members of the cabinet and their officials (the executive), not the elected representatives who are not members of the cabinet. By interactions, he meant the panoply of meetings in which the business of the federal system is conducted by the aforementioned individuals.

The zenith of these meetings are the socalled "summit" meetings, which are attended by the political leaders themselves. These meetings include the first ministers' conference (FMC) of the prime minister and the provincial premiers, and sometimes the territorial leaders. There are also regional conferences of the provincial premiers, like the Western Premiers Conference, the Conference of the New England Governors and Eastern Canadian Premiers (which includes Québec and the Atlantic provinces on the Canadian side), and the 
Atlantic Premiers Conference. At the next level are the meetings of ministers, for example the ministers of finance of all the governments, or the provincial and territorial ministers of education. Finally, the public servants who staff the intergovernmental meetings just mentioned hold intergovernmental meetings of their own.

There is no doubt that such meetings are important venues for the development of public policy, as well as useful occasions for participants to sort through difficult administrative issues. They are also elite exercises. As such, intergovernmental meetings raise concerns about legitimacy from the standpoint of their democratic credentials, and from the standpoint of the fairness of the process and the outcomes. On the democratic front, certainly executive federalism is not an inclusive phenomenon. The attendees are a slice of the governmental elite, a combination of elected and unelected officials. As well, the organized public is represented in the form of interest groups and even some public advocacy groups that have brought their influence to bear on the thinking of the officials on the agenda items of the day. Such groups have done their work in the preparation for the meetings. However, the unorganized public, or the vast majority of citizens, is not a participant.

The rejoinder is that the unorganized public is represented by the elected officials, which is a correct statement. And for some analysts, this form of representation - indirect democracy - is standard practice in liberal democracies today, and therefore takes care of the democratic concerns about executive federalism. ${ }^{4}$ The record of executive federalism since Confederation indicates that Canadians agree. Students of federalism still comment on this, particularly in connection with meetings that produce major public-policy decisions. Recent examples include the Agreement on Internal Trade (AIT), ${ }^{5}$ signed in 1995 by all governments, and the Social Union Framework Agreement (SUFA), ${ }^{6}$ signed in 1999 by all governments except Québec - and Québec was closely involved in the discussions. Richard Simeon and David Cameron point out that the negotiations on the AIT and SUFA were conducted with "minimal public involvement" and "very little public reaction."
On the other hand, there is the rare occasion on which the public has communicated serious concerns about the decision-making process, and governments have responded directly to those concerns. The Meech Lake Accord ${ }^{8}$ and the Charlottetown Accord ${ }^{9}$ - both multilateral agreements - are cases in point.

In 1987, the first ministers negotiated the Meech Lake Accord, a set of proposed amendments to the Canadian Constitution. Agreement was unanimous. Under the amending formula, the next step was for first ministers to gain support for the accord from their respective legislatures. Some did, but others ran into opposition, not just to the terms of the accord but also to the way in which it was negotiated, that is, by eleven "men in suits" - the phrase of opprobrium $d u$ jour - behind closed doors. There developed widespread public concern that the Constitution, only recently amended in 1982 by the addition of a popular Charter of Rights and Freedoms, ${ }^{10}$ was being manipulated somehow by political leaders who had failed to consult broadly about their purposes. In short, from the standpoint of the public the legitimacy of the process was questionable from a democratic point of view.

In response, some governments retreated from their earlier enthusiasm for the project and instead decided to consult with their respective provincial communities on the advisability of the accord. In the end, there simply was not enough public support for it, and the Meech Lake Accord collapsed. ${ }^{11}$ When the federal government launched the next or Charlottetown round, all of the governments fell into line on the need to avoid the "governments only" route of executive federalism and instead pursued broad-based consultation with the $\mathrm{Ca}$ nadian people. The process produced the Charlottetown Accord, another set of proposed constitutional amendments that was presented to Canadians in a referendum. They voted it down. Nevertheless, the episode shows that executive federalism can generate public concerns about the democratic legitimacy of the process that are strong enough to influence governments to alter their usual decision-making routine. ${ }^{12}$ What about perceptions of the fairness of the 
process and the outcomes of the process?

In executive federalism, a fairness norm has to do with the choice of players included in the process. For example, it has come to be regarded as fair to include territorial governments as well as provincial ones in these meetings. Similarly, in constitutional matters, Aboriginal leaders have long argued that they must be included as principal players along with the others. What I call a fairness norm of inclusiveness is not a hard and fast one. For example, the Aboriginal claim is not always honoured. But there is an exception - of sorts - that proves the importance of the norm. It occurred in a round of negotiations that brought the country the Charter of Rights and Freedoms. In November 1981, at a dramatic FMC, the prime minister and nine provincial premiers reached agreement on a set of amendments to the Constitution, including the Charter. The tenth participant, the Premier of Québec, unexpectedly found himself and his officials offside in the negotiations, the final decisions having been made without their participation. ${ }^{13}$

The Québec government did not simply take a dim view of the proceedings in November. It gained a resolution from the National Assembly denouncing the agreement. It went to court to argue that historically Québec had and continues to have a veto over constitutional amendments that affect it, an argument rejected by the Supreme Court of Canada (SCC). To this day, it holds that its exclusion from the critical moments of the decision-making process made the entire process an illegitimate one, and it has refused to sign on to the result of the process - the Constitution Act, 1982. ${ }^{14}$ Its refusal is symbolic because the document applies to Quebeckers as much as anyone else in the country. Nevertheless, it is a clear example of a process tainting the outcome in the eyes of some of the participants. The subsequent Meech and Charlottetown constitutional rounds were initiated in large part to respond to Québec's constitutional concerns.

In the examples canvassed thus far, the negotiations have been multilateral affairs involving proposed amendments to the Constitution. However, this is a small subset of the work of executive federalism. What about bilateral agreements? At the constitutional level, the federal government has concluded constitutional amendments with particular provinces on subjects peculiar to them. A recent example is the case of denominational schools in Newfoundland and Labrador. ${ }^{15}$ No one questioned the legitimacy of the process by which that amendment was accomplished.

Governments have also pursued a combination of multilateral and bilateral approaches in public policy fields. The federal government might outline an approach to be used in a particular field, and then proceed to negotiate agreements with as many of the provinces and the territories as is possible. Such a process was used in the negotiation of the labour market training agreements in 1996-7.16 Alternatively, governments might reach agreement on the principles guiding a public policy, and then proceed to a bilateral phase in which the federal government negotiates separate agreements with each of the provinces and territories under the umbrella of the general document. This path was followed in 2004-5 in the effort to establish a national early learning and child care system. ${ }^{17}$

In their account of the early learning and child care initiative, Martha Friendly and Linda White state that while some provincial officials prize the flexibility that bilateral agreements offer, others are less enamoured with them. They prefer the multilateral approach because it makes for more robust, national policy making. ${ }^{18}$ However, there is no indication that the participants or the public find such approaches to be unfair. Of course, there are bilateral agreements and bilateral agreements. In the cases of labour market training and child care, all of the governments were involved in the action even if, in the end, they declined to sign an agreement with Ottawa, as Ontario did in labour market training. What about bilateral agreements that are related to or have an impact on existing multilateral agreements, and yet are open only to some provinces to pursue? Here we approach the rarified universe of the Atlantic Accords. As we shall see, one of the many interesting features of these accords is that other (envious) governments attacked their legitimacy, and then made 
a point of communicating their concerns to their respective publics.

\section{The Atlantic Accords}

\section{Background}

The accords capped decades of regional economic and demographic decline in the Atlantic provinces relative to the central and western regions of the country. In the years following the Second World War, when government intervention in the economy to promote economic development was widely held to be the thing to do, political leaders in the region pursued various initiatives, none too successful. Therefore, it is easy to understand the excitement in Newfoundland and Labrador in 1979 when oil was discovered in the Hibernia field in the continental shelf 170 miles east of St. John's, at the very time when the global supply of oil and the demand for it turned in favour of producers over consumers.

The Hibernia find triggered a heated battle between NL's Progressive Conservative government, led by Premier Brian Peckford, and Ottawa over the ownership and control of minerals in the seabed under the waters off its coast, a battle with a pedigree. In 1965, Ottawa had referred exactly this issue in relation to the waters off the coast of British Columbia (B.C.) to the Supreme Court of Canada, and the Court ruled in favour of Canada over the province. ${ }^{19}$ In the years following the decision, the federal government took the position that the provinces with an offshore interest should benefit from the revenues that might accrue from the resources there, as do the provinces with onshore resources. It held that Canada has an interest as well, and that sound administration of the offshore requires that the federal government maintain final decision-making authority in the field. However, its efforts to negotiate agreements along these lines with the Atlantic provinces failed. In this pre-Hibernia period, the Atlantic provinces continued to hold out for the bigger prize of ownership of the resources. ${ }^{20}$

Post-Hibernia, of course, the stakes were rising in step with the upward shift in the world price of oil, a resource now thought to be scarcer than previously assumed. The federal government made a concerted effort to come to terms with Nova Scotia and Newfoundland and Labrador by offering more generous shares of the expected revenues and a system of joint administration of the resources. It agreed that these "have not" provinces ought to receive the lion's share of the benefits from the resources, at least until they reached the status of the "have" provinces. Both sides considered the offshore to be, among other things, a promising tool of economic development.

In 1982, the federal government finally reached an agreement with NS, the CanadaNova Scotia Agreement on Offshore Oil and Gas Resource Management and Revenue Sharing. ${ }^{21}$ As the title implies, the agreement set aside ownership considerations and focused instead on the issues of revenue sharing and joint management. NL, however, remained offside. Peckford argued that NL should have the same control and ownership of offshore resources as the provinces do in relation to the resources within their onshore boundaries, in order to propel itself from the ranks of the have-not provinces to the haves - and keep it there. His model was Alberta, then embarking on a petroleum bonanza. Ottawa, too, envisaged a bright future for the province and the end of its reliance on equalization payments. But it disagreed with Peckford on the issue of ownership, expected a substantial share of revenues from the resources for itself, and had no plans to cede control of the pace of their development to the province. ${ }^{22}$

In the end, the NL government asked the Newfoundland Court of Appeal to determine the issue of the ownership of the offshore resources. The federal government then sent its own, narrower question about legislative control of the Hibernia oil field to the Supreme Court of Canada. The NL court issued a split decision, finding for the province on the three mile territorial seabed, where there is no oil, and for the federal government on the continental shelf. ${ }^{23}$ The SCC reached the same decision as the Newfoundland court on the continental shelf. ${ }^{24}$

Newfoundland and Labrador clearly lost the offshore jurisdictional round. Worse, in 
1984 the SCC upheld the contract signed between Newfoundland and Québec in 1969, that for sixty-five years gives Québec the lion's share of the power and the profits from the electrical power development in Churchill Falls, Labrador. ${ }^{25}$ The province's fortunes took a turn for the better, however, when the PC party led by Brian Mulroney won the 1984 general election. The Peckford government negotiated the Atlantic Accord with the Mulroney government in 1985. Eying this development, NS abandoned its 1982 agreement and instead took advantage of the option to negotiate its own accord with the federal government a year after NL did. It is now time to summarize the key provisions of the accords.

\section{The content of the accords}

The two accords were similar in content and organization. Each opened with a statement of the overall objectives of developing the offshore resources for the benefit of Canada in general and the province in particular ("chief beneficiary" in the case of NL; "principal beneficiary" for NS). There followed a list of objectives couched in somewhat different wording but ranked in the same order, the only exception being a final, additional objective in the Nova Scotia list on the subject of Crown shares of the resources. The themes of the objectives were: management policy, revenue-sharing policy, and development policy.

On management policy, the operative terms were "equality," “joint," and "stable." In both documents there were references to the use of systems of joint management, in which the federal and provincial governments are equal partners. There was also reference to the desirability of establishing a stable, administrative regime for the offshore petroleum industry. On revenue sharing, the objective was that the provinces receive the lion's share of the revenues, just as they would if the resources were on the land within their boundaries, until they reach a specified level of fiscal capacity, after which Canada's share of the revenues was expected to increase. In the case of NS, there was also provision for the province to acquire revenue (Crown payments) that might have been gained by owning a share of a project, a share that the province could have purchased, but did not.

It was anticipated that there would be a decline in equalization payments to the provinces in the wake of revenues flowing from the offshore. Accordingly, there was provision for equalization offset payments. In the NL accord, Canada agreed to make payments for a period of twelve years that would "offset" the expected decline in equalization payments. In other words, there was an agreement to shelter offshore oil and gas resource revenues from a clawback through the equalization program. In the NS accord, the same commitment was made for a ten-year period by continuing the equalization offset provisions in the earlier but now superseded Canada-Nova Scotia Oil and Gas Agreement (Nova Scotia) Act. ${ }^{26}$ The period of the offset payments was later extended for both provinces.

It should be noted here that under the equalization program itself, provision was made in 1994 to shelter the resource revenues of have-not provinces from the treatment they would otherwise receive. Called the "generic solution," the idea was to use only 70 percent of the revenues gained from a particular revenue source (in which source an equalization-receiving province has more than 70 percent of the total revenue base of the country) for purposes of calculation, rather than 100 percent. For such a province, this meant that the remaining 30 percent was sheltered from a clawback. Under the accords, in any given year NS and NL could choose the generic solution or the newly-negotiated offset provisions.

Finally, there was the theme of economic development in the accords. The statement of objectives referred to the need to pace the development of the industry so as to enhance the economic and social benefits (NL), and employment and industrial benefits (NS) of the offshore for the provinces and Canada. Each province received a development-fund payment that was intended to assist in financing infrastructure costs associated with the establishment of the industry. In the NL accord, there was a section entitled "Economic Growth and Development," the aim of which was to ensure that the province and its residents get "first con- 
sideration" for contracts for goods and services as well as employment training programs and employment generally. In the NS document, the section was entitled simply "Benefits," and the content was similar.

The accords were bilateral political agreements between Canada and each of the two provinces, and the parties to the agreements passed detailed implementation legislation to give effect to the provisions of the accords. But they were bilateral agreements that implicated the equalization program, itself a core multilateral agreement among Canadian governments, established in 1957 and despite changes made from time to time in the formula, in effect ever since. Indeed, in 1982 the commitment to equalization was entrenched in the Constitution. The purpose of the program is to enable Canadians to count on reasonably comparable public services at reasonably comparable levels of taxation, no matter where in the country they choose to live. Thus, it is widely held to be a hallmark of fairness and equity in the federation.

\section{Equalization and the "fair shares" campaign}

In due course, the expectations generated by the prospect of a robust offshore petroleum industry looked to be overly enthusiastic. There were fewer large finds than anticipated initially. The price of oil declined from a high of $\$ 37.42$ in 1980 to a low of $\$ 11.91$ in 1998 , although thereafter it began to climb. ${ }^{27}$ As well, the offset payments negotiated in the accords, diminishing each year, were due to expire altogether by 2012 for NL and 2004 for NS. The fallback was the generic solution, but as indicated above it sheltered only 30 percent of the revenues from the resources, thereby exposing the remaining 70 percent to a clawback. The size of the clawback was the straw that triggered the fair shares campaign.

John Hamm's Progressive Conservatives gained office in NS in 1999, while Roger Grimes succeeded Brian Tobin as premier of NL in February 2001. Hamm launched Nova Scotia's "Campaign for Fairness" in January 2001. According to the government's website, the purpose of the campaign was to procure the province's "rightful share" of revenues from off- shore oil and gas developments so that it could maintain a stable economy and reduce its dependence on transfers from the federal government. ${ }^{28}$ This was the perspective of the offshore as a major tool of economic development. There was also a reference to the provision in the accord that NS be the principal beneficiary of the offshore. ${ }^{29}$ The clear implication was that in seeking its rightful share of the revenues flowing from the offshore, the province was asking the federal government to keep its promise. In a speech to the Canadian Club in Toronto later that year, Hamm observed that, contrary to the accord, Ottawa was turning out to be the principal beneficiary instead of NS, gaining 80 cents of every dollar of revenue flowing to the governments. ${ }^{30}$ Such was the argument and it was pretty straightforward.

Hamm's fairness campaign initially was an exercise in public education, both for the province and the country. Nova Scotians could read the arguments online, and if they did were invited to fill in an online form as a show of support. For his part, the premier undertook a series of public-speaking engagements in the province and in Ottawa, Toronto, and Calgary. It was not without some success. His campaign garnered a supportive editorial in the National Post in June, ${ }^{31}$ and the endorsement of Premier Ralph Klein of Alberta in the same month. ${ }^{32}$ Adding punch to the effort, Grimes joined forces with Hamm in August 2001.

In a move that signaled his government's unhappiness with the offshore-equalization conundrum, Grimes established a royal commission on NL's place in the federation in 2002. ${ }^{33}$ The terms of reference of the commission included any arrangements between the province and Canada that proved counterproductive to the province's quest for prosperity and self reliance, in particular, federal jurisdiction over the offshore resources. ${ }^{34}$ In its 2003 Report, the commission noted the 2012 expiration of the offset provisions of the accord. Thereafter, the province's share of the revenues was expected to decline substantially, while the federal government's share was to rise. In the words of the Report, "over the life of the existing projects [Hibernia, Terra Nova, and White Rose], the net 
amount of revenue that the provincial government retains will pale in significance when compared with the combined impact of the federal government's savings from reduced equalization payments and its federal corporate income tax." ${ }^{35}$ The commission drew the comparison between this state of affairs and the words of the accord, under which NL is to be the primary beneficiary of the offshore petroleum resources. Accordingly, it made the recommendation that the accord be revised to assign NL a much larger share of its own provincial revenue (meaning the continuation of the shield from the equalization clawback), and a larger net share overall (meaning that the federal government should take comparatively less), as long as it remains a have-not province. ${ }^{36}$

Despite glimmers of support elsewhere, the fair shares campaign cut little ice in Ottawa, where the majority Liberal government was enjoying a third term under Prime Minister Jean Chrétien. However, party leadership and electoral changes were afoot and they would transform the prospects of the campaign. In November 2003, long-time aspirant for the leadership of the Liberal party, Paul Martin, managed to orchestrate the departure of Chrétien and take over the helm of the governing party and therefore the country. Meanwhile, a month earlier in the general election in NL, Progressive Conservative leader Danny Williams secured a convincing win over the Grimes government by taking 34 of the 48 seats in the province's legislature.

A successful businessman before entering politics, Williams took no time at all to pick up where Grimes left off on the fair shares theme. He forcefully articulated the view that offshore revenues are tantamount to a windfall from a nonrenewable resource and ought to be treated separately from equalization payments, that is, not included in the calculation of the payments. The equalization payments, he argued, should stop only when the province's fiscal capacity was high enough to make it ineligible to receive them. He got nowhere, of course, until Prime Minister Martin called a federal election for 28 June 2004. Then he hit pay dirt.

Although many had expected Martin to produce the fourth Liberal majority in a row, the campaign began to falter in the wake of revelations about the misuse of public funds used to advertise the support of the federal government for community activities in Québec. The scandal came to light in February, and Martin quickly established a public inquiry to deal with it. Nevertheless, an unending string of news reports implicating the Liberal party in the scandal weakened public support for the Liberals during the campaign, and opinion polls began to forecast another minority Liberal government. Now every seat counted, and in an effort to pick up an extra one in NL, Martin promised Williams to end the clawback of 70 percent of the province's offshore revenue share under the equalization scheme - apparently in the course of a 5 June telephone call. ${ }^{37}$ This extraordinary development bought the Liberals an additional seat in NL, but also the start of a rancorous feud with Williams over the content of the promise made over the telephone.

\section{Minority Government Politics and Bilateral Agreements: Round 1}

The Martin government was politically vulnerable to provincial demands for more cash, not simply because it was a minority government but because it had the cash. It was running record annual surpluses. In light of Martin's insistence during the election that there was an urgent need to shorten "wait times" for health care services, in September the government held a health care summit with the provinces and the territories, and agreed to a significant increase in transfers to them for health care over the next ten years. The provinces and territories were happily united in this effort. The next meeting set for October promised to be much trickier, since the subject was an equalization "top up," and the provinces were divided in their views on the subject.

During the health care meetings, Ottawa had announced that it was prepared to deliver an additional $\$ 1.7$ billion in equalization funds (for a total of $\$ 10.9$ million in 2005-6, rising by 3.5 percent per year after that) to the have-not provinces at the time, meaning the four Atlantic 
provinces, Québec, Saskatchewan, Manitoba, and B.C. The Atlantic provinces preferred to see the money doled out along the same lines as the main program, while Québec advocated that it be distributed on a per capita basis. ${ }^{38}$ Then, a few days before the meeting, the media reported that Québec, Manitoba, and New Brunswick had drafted a discussion paper in which they argued for a change in the equalization formula to include the tax bases of all ten provinces in the calculations, including Alberta's rich natural resource tax base. The effect would be to increase the size of the equalization pot by 50 percent, from $\$ 10$ billion to $\$ 15$ billion, ${ }^{39}$ an amount that Québec regarded as a down payment on what it termed the "fiscal imbalance," that is, the imbalance between provincial and territorial expenditures and the money to pay for them. The proposal was not well received by the wealthier provinces. Ontario Premier Dalton McGuinty issued a warning that there were limits to the province's generosity in the redistribution program. ${ }^{40}$

Meanwhile, there were reports that Ottawa was close to a deal with NS and NL to end the clawback of offshore resource revenues - in other words, to fulfill Martin's telephone promise to Williams. If accomplished, it was speculated, the deal would keep these two have-not provinces from joining the Québec-led campaign for more equalization dollars and thereby lessen the pressure on Ottawa to respond to it. ${ }^{41}$ Williams repudiated the speculation, pointing out that the accords needed to be fixed on their own and had nothing to do with the equalization question per se. As matters transpired, however, there was no deal before the meeting of the first ministers on equalization that was set for $25 \mathrm{Oc}-$ tober 2004. Instead, on the eve of the meeting Ontario's McGuinty noted the province's pride in backstopping equality of opportunity across the country, and then warned that it would not support the efforts of the have-not provinces to wring more equalization money out of Ottawa. There were "limits," McGuinty said, to Ontario's capacity and willingness to contribute more to the country than it received back, and he remarked that the province's net contribution for the year was some $\$ 23$ billion. $^{42}$
Before the meeting on equalization got underway on 25 October, Williams caused a ruckus by boycotting it. Before flying back to NL, he told the media that he and his officials had been holed up in Ottawa all weekend waiting in vain for the prime minister to call to seal the deal on the 5 June telephone promise to eliminate the equalization clawback of offshore resource revenues. Instead, they found themselves contending with federal officials who were trying to change the promise by introducing caps on the amount to be protected by the clawback. ${ }^{43}$ Therefore, it was in the absence of NL that the first ministers reached an agreement on equalization that was largely the offer that Ottawa had made to them during the health care meetings a month earlier. The federal government also planned to establish an independent panel of experts to review the equalization system. ${ }^{44}$

The drama over the accords intensified. Nova Scotia was still talking to federal officials, but not Newfoundland and Labrador. A war of words erupted between St. John's and Ottawa over the exact content of the infamous promise, Williams saying it was unconditional, the federal government saying it included a cap, which it now defined as a fiscal capacity equivalent to that of Ontario. That definition, easily understood, appeared to put the matter in a different light for some in the media. As the controversy dragged on, the press began taking sides. In the West and Ontario, journalists perceived Williams to be asking too much, as indicated by this statement from Don Martin, a columnist with the Canwest newspaper chain: "[Prime Minister] Martin correctly counter-argues Newfoundland should be cut off from the trough as soon as it reaches the fiscal level of Ontario, one of the two richest provinces in Canada." 45 The positive reaction to the earlier fair shares campaign was turning sour. In NS and NL, on the other hand, journalists took the other side, inveighing against the conditions Ottawa sought to place on its offer. ${ }^{46}$

The fight escalated throughout the remaining months of 2004, causing the prime minister not a little discomfort. NL Liberal MPs, crosspressured, criticized their own government as well as Williams. The minister of natural re- 
sources, John Efford, NL's only federal cabinet minister, found himself alone in defending the government's offer. At its convention in NL, the province's Liberal party backed the position of the premier, a Progressive Conservative. ${ }^{47}$ Even Brian Mulroney, the Progressive Conservative prime minister under whom the accords were established, waded into the affair, urging the federal government to deal with NL and NS on their terms. ${ }^{48}$ In addition, NS Premier John Hamm, whose officials continued to talk to federal officials about the situation, stood by the intransigent Williams. Federal Conservative opposition leader, Stephen Harper, was quoted as expressing "great admiration for Premier Hamm in sticking by Newfoundland and not allowing the federal government to play this game of divide and conquer." ${ }^{.49}$

Faced with a deteriorating situation over which he had lost control, Martin publicly stated his desire to reach a satisfactory agreement with the two provinces, and the officials involved continued the negotiations, although it was clear that Ottawa was still insisting on caps in the form of a time limit on the deal, and a clause that would link the resumption of the equalization clawback to Ontario's fiscal capacity. The last meeting of the year attended by the two premiers and Finance Minister Ralph Goodale, in Winnipeg, proved to be a disaster. Unhappy with the negotiations, Williams stormed home and ordered that the Canadian flags on provincial buildings be taken down, a symbolic move of the first order that was not especially well received elsewhere in the country. ${ }^{50}$ Martin refused to reopen the talks until the Canadian flags were flying again in NL, and Williams refused to fly them until Martin publicly agreed to address the province's grievances. Meanwhile, one of the country's national newspapers sternly advised Williams to carefully consider Ottawa's offer to the province and put an end to the flag gambit. ${ }^{51}$

Ottawa and the two provinces finally reached a deal at the end of January 2005. Setting aside the complicated details, the main provisions were these: first, the provinces would receive all of the revenues from the offshore resources to which they were entitled; second, Ottawa would offset any reduction in equalization payments charged against the resource revenues until the provinces no longer qualified for equalization, and in that event they would receive transitional payments for another two years; third, the provinces would be understood not to qualify for equalization if they met a particular fiveprovince standard of fiscal capacity then in use; and four, the offset payments were available, if required, for sixteen years (defined as two eightyear periods). The deal was estimated to be worth some $\$ 1.1$ billion for NS (\$830 millions upfront) and $\$ 2.6$ billion for NL ( $\$ 2$ billion upfront). Amidst the general cheer, John Hamm pointed out that four years had passed since the start of his fair shares campaign. ${ }^{52}$

\section{Negative reaction}

Any sympathy initially expressed outside Atlantic Canada for the fair shares campaign evaporated, to be replaced by a growing chorus of criticism of the outcome - the two deals. Or, rather, the "side deals" as they were quickly dubbed by commentators. Influential journalist Margaret Wente said she wanted "Danny Billions" on her side in a column in which she managed to sound each of the points developed in public discussion of the deals over the next two years: Williams behaved badly, albeit successfully, in holding out for more than he should have; Martin showed no spine in the face of provincial special pleading; the principle of equalization was in tatters; and people in the "mainland" - read Ontario - felt "ripped off" by the side deals. ${ }^{53}$ The first two are fascinating for those who enjoy the gamesmanship of political life. The latter two are critical in the discussion of the effect of the accords on intergovernmental relations.

On the first point, commentators quickly framed the deals - and the deal makers - as saboteurs of equalization rather than as instruments of economic development. The idea of equalization is to ensure that the provincial and territorial governments can offer their residents access to reasonably comparable public services at reasonably comparable levels of taxation. The Martin government had already compromised the execution of the principle in the eyes of many analysts by taking the existing pot and 
capping it by a specified annual rate of growth, rather than letting it ebb and flow in response to the circumstances of the provinces from year to year. To be fair, however, as noted above the government had also appointed a commission to examine the equalization scheme, and so the cap decision could be viewed as a holding operation until the commission issued a report and recommendations of change, if any, to the scheme. By contrast, according to some writers the accords skewered the very heart of equalization.

The argument was simple enough. From its inception in 1957 until 2004 and the Martin cap, the equalization program was formuladriven. Whether or not a province or a territory was an equalization recipient was an outcome of the application of the formula in use at the time, not an ad hoc outcome of a bilateral deal with the federal government. Further, being formula-driven meant that the outcome in any given year would reflect the province's fiscal capacity. In theory, the greater its relative tax yields, the less the province receives in equalization. A bonanza in the form of lucrative offshore revenues might mean no equalization at all unless, of course, a province negotiated a deal with the federal government to set aside the rules that applied to everyone else. The Globe and Mail was prepared to buy the exceptional treatment of NL (and by implication NS) "as an investment in a very poor province." However, it was decidedly upset by the transitional payments that would continue to be paid to the province when it attained "have" status (stating that in this respect Martin had "exceeded his brief"), by the fact that there were no strings attached to the upfront payments, and by the fact that Williams' "flag antics" had succeeded in getting the province a better deal. Martin, according to the newspaper, "is clearly willing to give away the store to buy provincial peace." ${ }^{44}$ And Saskatchewan was waiting in the wings to press a "side deal" of its own.

The Saskatchewan case alerted everyone to the difficulty involved in getting the equalization scheme back on track. Premier Calvert said that as long as Saskatchewan was a "have" province it was content to forego equalization payments, meaning he was not demanding anything like the terms negotiated with NL and NS. On the other hand, he argued, should the province fall back to "have not," equalization-receiving status, then its oil and gas revenues ought to be protected from federal clawbacks: it should have its natural resource revenues and equalization cake, too. In his initial public pitch, Calvert suggested that he would take a determined, yet civil approach to the issue rather than the approach adopted by Williams. ${ }^{55}$

Ontario's opening shot in the debate followed shortly on Calvert's comments, and it goes to the second point Wente made about people feeling "taken" by the deals with NL and NS. Premier McGuinty made the claim that Ontario taxpayers would be paying for the deals, and that this was "patently unfair" to them. (Since Ottawa doles out equalization payments from general revenues, which means that every taxpayer in the country contributes to the program, McGuinty's claim was misleading.) He added that the province annually contributed some $\$ 23$ billion more to the federal treasury than it received in services, while his own government was running a budget deficit. McGuinty also pointed out that NL's fiscal capacity would soon surpass Ontario's, an unacceptable outcome in his view for an equalization-receiving province. He planned to launch a campaign to persuade the federal government that the arrangements with NL and NS had thrown the equalization scheme off course. ${ }^{56}$ Meanwhile, New Brunswick and B.C. said they were looking for side deals, too.

At least one of the national newspapers supported McGuinty. It argued that the equalization program can have the perverse effect of penalizing economic growth that threatens the receipt of equalization payments - apparently the problem for NL and NS. This, in turn, has negative effects for the provinces that underwrite equalization. "By starving Ontario of \$23billion per year so that other provinces and cities can keep unproductive regions on economic feeding tubes," the newspaper opined, "the country is depriving its economic engines of the infrastructure and services they need to compete internationally." ${ }^{57}$ In the end, McGuinty 
succeeded in negotiating a five-year deal with Ottawa worth $\$ 5.7$ billion for programs in areas like postsecondary education and immigration, which he called a "downpayment" on the $\$ 23$ billion, thereby signaling his expectation of more to come. ${ }^{58}$

\section{Minority Government and Bilateral Agreements: Round 2}

The second round of the Atlantic Accords implicated the equalization formula more closely than the first. On equalization, provinces like Saskatchewan as well as Newfoundland and Labrador argued for the removal of natural resources revenue from the formula altogether, for the obvious reason that the change would benefit them. If this were to happen, their own high natural resource revenues would not work against them in equalization terms. Since the equalization formula was due for an overhaul, the issue became a highly controversial one, beginning with the next general election.

By the fall of 2005, it was clear that the days of the Martin minority government, beset by indecisiveness and scandal, were numbered. On 23 November the opposition parties passed a vote of want of confidence in the government and the scene was set for an election on 23 January 2006. In its campaign platform, the Conservative Party called for changes to the equalization formula to ensure that "non-renewable natural resource revenue is removed from the equalization formula to encourage economic growth," adding that no province would be "adversely affected" by any such changes. ${ }^{59}$ In addition, on 4 January 2006 the Conservative leader, Stephen Harper, sent a letter to Premier Williams in which he reiterated the plank, using practically the same words. ${ }^{60}$ The campaign plank and letter were consistent with the position Harper had articulated in a letter to Williams two years earlier when he was running for the leadership of the Conservative Party. ${ }^{61}$

The election produced a Conservative minority government, and one of its tasks was to figure out what to do about equalization in the context of a budget surplus. There was no shortage of advice. One national newspaper urged the new government to drop the Conservative campaign proposal. "The situation [would be] so farcical [under it]," it wrote, "that Ontario residents could end up paying for transfers to Newfoundland and Saskatchewan and eventually British Columbia, even though those provinces would actually have a higher fiscal capacity per capita when all revenues were taken into account." ${ }^{2}$ Ontario opposed an enrichment of the equalization program, instead demanding extra money from the federal government in the form of transfer payments for various social programs. ${ }^{63}$ By contrast, in March a panel appointed by the Council of the Federation recommended an enriched equalization program based on a ten-province standard that included 100 percent of natural resource revenues. ${ }^{64}$ Québec too urged the federal government to provide more equalization monies - it is an equalization recipient - in order to repair the so-called fiscal imbalance, a concept which it had been hawking for months. Alberta's Premier Klein threw a real clanger into the discussion by threatening to pull the province out of the equalization program if it was enriched by the inclusion of natural resource revenues. ${ }^{65}$ Then, the federal government released the much-awaited report of its Expert Panel on Equalization and Territorial Formula Financing, generally known as the O’Brien panel after its chair, Al O'Brien. ${ }^{66}$

The panel recommended an enriched equalization program that uses a ten-province standard of revenue-raising capacity, and the inclusion of 50 percent of natural resource revenues. It also proposed a cap on potential payouts to provinces, so that "no [equalization-]receiving province ends up with a fiscal capacity higher than that of the lowest non-receiving province." ${ }^{\prime 7}$ The cap would have the effect of clawing back natural resource revenues in NL and eventually NS. And the 50 percent inclusion rate was not what the Conservative party had promised to do before - and during - the election campaign just past.

However reasonable the panel's recommendations were in total, it was impossible to please everyone. In the weeks following the release of the O'Brien Report, the political actors and their supporters made their pitches to one an- 
other and to the attentive public following the debate. The federal government shrewdly bided its time, playing up the lack of consensus on the appropriate equalization "fix," while one of Prime Minister Harper's long-time supporters, Ken Boessenkool, praised the O'Brien panel's work: "by proposing a middle ground on resource revenues and by designing a clever cap to prevent the program from becoming unaffordable, the panel has both given impetus to critics and provided a compromise on two instractable issues." ${ }^{8}$ Boessenkool's article was a signal of the government's positive view of the report.

Ontario economists weighed in on McGuinty's side, arguing that in the light of its economic travails, including a manufacturing sector faltering in the face of a strengthening dollar, the province could ill afford to finance an enriched equalization program. ${ }^{69}$ Following a tour of Atlantic Canada in an effort to explain his government's position, McGuinty himself took a more conciliatory line on the eve of a meeting of the premiers in St. John's, NL on equalization, offering to accept a richer equalization program in return for higher federal transfers for health care and social programs. ${ }^{70}$ However, the premiers were unable to reach a consensus on any aspect of fiscal federalism, let alone equalization, in what appeared to have been rather acrimonious discussions. According to the host of the meetings, Williams, it was now up to each province to convince Ottawa of its point of view. ${ }^{71}$

Williams crossed swords with Harper in the fall, when the prime minister traveled to NL in October to attend the annual Progressive Conservative convention there. He tried to get Harper to repeat his pledge to keep nonrenewable energy resources out of the equalization formula, which he now declined to do, an obvious signal that he was reconsidering his position. ${ }^{72}$ While Williams publicly berated the prime minister's hesitation and threatened to campaign against him in the next federal election if he abandoned his pledge, the new Progressive Conservative premier of NS, Rodney MacDonald, pointedly stuck to the art of persuasion. ${ }^{73}$ The prime minister maintained that the decision would be made in the spring budget of 2007.
Other resource-rich provinces were just as concerned about the treatment of natural resource revenues, and by the beginning of 2007 Alberta, Saskatchewan and B.C. had lined up behind Nova Scotia and Newfoundland and Labrador in calling for their exclusion from the equalization formula, all of them being better off under the exclusion option. The crucial difference, however, was on the have-not side between Saskatchewan and the two Atlantic provinces. Saskatchewan had no deal with the federal government to shield its natural resource revenues from an equalization clawback.

In March, the Conservative government brought down its second budget, including a revamped equalization program clearly based on the O'Brien Report. It opted for a ten-province standard, 50 percent exclusion of natural resource revenues, and a cap under which equalization payments could not move a recipient province's total per capita fiscal capacity above that of any non-receiving province. Further, the federal government made the claim that NL and NS would maintain the benefits of the accords, but it offered them a choice. They could choose the new equalization program, and enjoy richer equalization payments immediately flowing from the ten-province standard than they would under the existing program with its five-province standard; but 50 percent of resource revenues would count for the clawback, and there would be a cap on the overall size of equalization payments. Alternatively, NL and NS could choose the existing system with its lower payments and the benefits of the accords. ${ }^{74}$ It was a clever move that enabled the federal government to say that it continued to honour the accords. It also backfired, producing an epic battle between the federal and two provincial governments. For a time, intergovernmental affairs were out of control.

It is hard to exaggerate how negative the reaction was to the budget decision in NL and NS. It was far more bitter than opinion during the previous set-to of the two provinces with the Martin government, and drew the attention of the public as well as governmental actors. Although few could grasp the complex calculations involved, everyone understood the claim 
of the province that the federal government essentially was reneging on the accords. In Halifax, the Chronicle Herald produced an editorial entitled "Harper locks Nova Scotia in new ice age," and scoffed at the prime minister's insistence that he was keeping his promise to the province rather than getting around it. ${ }^{75} \mathrm{In} \mathrm{NL}$, the decision was immediately branded a betrayal by the premier and the government took out a full-page ad in major newspapers across the country to say as much. ${ }^{76}$

There followed a long period of negotiations between officials of the federal government and the two provinces, punctuated by openly warring political actors, each side in competition for public opinion in the region. They took out ads in the newspapers, denouncing one another's positions. They fought the battle on governmental websites. They threatened legal action against one another. They even argued the facts. The federal finance minister published what amounted to an editorial in a Halifax newspaper in which he called the claim that his government was abandoning the Atlantic Accords an "urban myth." 77 Then, two economists in NL and NS entered the fray with analyses to demonstrate that the option of the new equalization program (plus the cap) - contra the federal finance minister - would leave the provinces worse off than the status quo. ${ }^{78}$

The open political fighting was chaotic. Moreover, the parliamentary context was tenser than usual because the federal government's decision on equalization and the accords, being part of the budget, was a matter of confidence. While Williams conducted a war of words against the federal government from St. John's, MacDonald tried to negotiate his way out of the dilemma. He also resorted to an array of tactics, like pressuring Nova Scotia MPs to vote against the government on the budget vote - Bill Casey did, and was ejected from the Conservative caucus for doing so. ${ }^{79}$ MacDonald pled his case in the media, broke off negotiations with the federal government and then re-entered them, took his case to the Senate, and threatened court action. Apparently to no avail.

Parliament passed the budget, but the need for implementation legislation meant that there was still room to negotiate the issue. Fully aware of that fact, McGuinty warned the prime minister not to make any "special deals" with the two provinces that would confer on them a greater per capita fiscal capacity than Ontario. ${ }^{80}$ Boessenkool wrote another column in which he praised the federal government's effort to return to a formula-driven equalization program and warned NS and NL that in "hankering" after special deals, they were undermining the legitimacy of the program in the eyes of the wealthy provinces. ${ }^{81}$ One national newspaper penned the same themes in an editorial that concluded with this bit of advice to the two Atlantic provinces: "The mice should be careful not to bite off more than the country will let them chew." 82 Picking up on the flavour of these sentiments, one local columnist warned Atlantic Canadians that "Ontarians overwhelmingly believe the equalization system, unless reformed, will be a permanent drain on their pocket-books." ${ }^{83}$ Interestingly, a public opinion poll on equalization conducted during the contretemps showed that nationally there was more support for the two Atlantic provinces than the prime minister - although that was not saying much - and in Atlantic Canada almost none for Harper's position. ${ }^{84}$

In the end, and following a summer of noticeably sour behaviour on the part of the prime minister towards the two Atlantic premiers, ${ }^{85}$ the federal government reached an agreement with NS in October 2007. The parties agreed that NS would do at least as well under the new (and better) equalization formula than it would have done under the formula in place at the time of the 2005 accord - and for the lifetime of the 2005 accord. In other words, should NS choose the new equalization formula (as it clearly meant to do), and thereby give up the protections of the 2005 accord, it would not be penalized for that choice. In return, the province agreed to accept less money in the near term in return for more generous payments down the road. In addition, the two sides also agreed to establish an independent panel to resolve the matter of the Crown shares, that is, the size of the payments owing to NS for shares in offshore energy developments to which it was entitled under the terms of the 1986 Atlantic Accord. ${ }^{86}$ 
The agreement did not produce an enthusiastic chorus of approval. Nationally it was reported as a compromise under which NS got less than it demanded but more than it was initially offered in the March budget. ${ }^{87}$ In Nova Scotia, it was described as a "wimpy deal," a "gamble" and a special deal, the later, generous payments of which might prove difficult, down the road, to defend against jealous provinces. ${ }^{88}$ Fresh from his huge election win in $\mathrm{NL},{ }^{89} \mathrm{Wil}-$ liams said that Ottawa had taken advantage of MacDonald's weakness as leader of a minority government to get the deal, while Premier Calvert derided it as a special deal and immediately called a provincial election in which he clearly planned to campaign on the unfairness of the whole thing. ${ }^{90}$ No one seemed to be able to find the deal anyway. There was a published exchange of letters between the federal finance minister and his NS counterpart, but it was weeks before the required implementation legislation appeared..$^{1}$

Mindful of the next federal election and the futility of Conservative prospects in NL should the premier campaign against the government, the prime minister sought to mend fences with Williams. According to Williams, the price of peace was $\$ 10$ billion paid over 15 years, an amount he said the province would lose in equalization under the offer made to it in the federal budget. ${ }^{92}$ In December, the province's finance minister announced a "record-shattering \$882-million surplus" for the fiscal year, most of which would be set against the crippling provincial debt, but he was quick to add that this surplus had no bearing on the equalization issue. $^{93}$

That same month, there were suggestions in the media that Williams had "quietly" made the same deal with the federal government as MacDonald. ${ }^{94}$ He quickly repudiated the idea in a news release, stating unequivocally that the government had not signed any equalization deal but instead was confronted with the same unpalatable choice made available to it all along, a choice it would eventually be forced to make. ${ }^{95}$ Evidently, the prime minister had not come to terms with William's demand for $\$ 10$ billion. In April, the NL's finance minister announced the decision to stay with the old equalization formula and the Atlantic Accord. From the standpoint of the long term financial interest of the province, he said, it was a better bet than the new equalization formula. ${ }^{96}$

\section{Conclusion}

The first question posed at the outset of this article is whether the Atlantic Accords are regarded as legitimate agreements in Canada. The concept of legitimacy itself has been elaborated in terms of democracy and fairness. Throughout the epic struggles of the accords, no one launched an attack on the intergovernmental proceedings for being undemocratic. Instead, it was all a matter of fairness. Critics attacked the procedure, and then the outcome of the procedure. On procedure, they said that the renegotiated accords were unfair because they were bilateral agreements that implicated multilateral agreements affecting all of the players. The term continually used to describe them, "side deals," implies that they were unsavoury, backroom, political deals in which one side was able to take advantage of the political weakness of the other side. On content, the critics said that the renegotiated accords unfairly gave two have-not provinces special treatment not made available to other have-not provinces. Worse, they violated the principle of the equalization program by securing for two provinces ongoing equalization payments, alongside rising revenues from the offshore resources. To the extent that they were perceived to be unfair, then, the renegotiated accords were regarded as illegitimate.

The second question is whether any of this matters for NL and NS in particular, and for the health of the federation in general. I would say yes on the first count simply because the critics are unlikely to forget about the accords for a long time. One of them, the federal government, relentlessly sought to undo the Martin telephone promise from the day it was made in June 2004. Moreover, it must have found the open conflict with NS and NL trying, to say the least. Such conflict is the sort of experience that could cloud the relationship between it and the two provinces for years. Then there is Ontario, the most prominent of the provincial 
critics. The media based in Ontario have been running a steady series of reports and commentaries to sound the alarm on the province's declining economic prospects. ${ }^{97}$ The equalization program itself is now a target of criticism, and not just by business columnists and the Ontario Chamber of Commerce. ${ }^{98}$

Premier McGuinty is campaigning to overhaul the equalization program, saying that Ontario is picking up more than its fair share of the tab for equalization. Referring to reports that it is on the brink of becoming a have-not province, he wants to keep more of the money at home. The idea of Ontario as a have-not province - an equalization taker - has been until very recently unthinkable; ${ }^{99}$ it also implies a smaller pot of equalization dollars. This strikes some as a worrying prospect for NS, since equalization makes up almost one-fifth of the province's budget. ${ }^{100}$ In the future, the province might well face an unsympathetic audience should it need to lobby for better equalization treatment. On the other hand, NL is heading towards "have" status, and in sticking with the accord and the old equalization formula, might have wound up making a better choice than NS anyway.

As for the federation, it is tempting to think that it will weather the storm. Certainly the changing economic circumstances of the regions of the country are driven by forces more powerful than the accords and equalization. On the other hand, the equalization program has long been a symbol of the commitment of Canadians and their governments to horizontal fiscal equity, that is, the capacity of individual provinces and territories to deliver comparable levels of services at reasonably comparable rates of taxation. Arguably any weakening of that commitment is a weakening of the ties that bind the federation.

\section{Notes}

* Jennifer Smith, Department of Political Science, Dalhousie University.

1 Canada, Memorandum of Agreement Between the Government of Canada and the Government of Newfoundland and Labrador on Offshore Oil and Gas Resource Management and Revenue Sharing
(11 February 1985), online: Canada-Newfoundland and Labrador Offshore Petroleum Board $<$ http://www.cnlopb.nl.ca/pdfs/guidelines/aa_ mou.pdf $>$.

2 Canada, Canada-Nova Scotia Offshore Petroleum Resources Accord (26 August 1986), online: Government of Nova Scotia <http://www.gov.ns.ca/ energy/resources/RA/offshore/1986-Canada-NSOffshore-Petroleum-Resource-Accord.pdf $>$.

3 Donald V. Smiley, Canada in Question: Federalism in the Eighties, $3 \mathrm{~d}$ ed. (Toronto: McGrawHill, 1980) at 91.

4 Jennifer Smith, "Representation and Constitutional Reform in Canada" in David E. Smith, Peter MacKinnon \& John C. Courtney, eds., After Meech Lake: Lessons for the Future (Saskatoon, SK: Fifth House Publishers, 1991) 69.

5 Canada, The Agreement on Internal Trade (18 July 1994), online: <http://www.ait-aci.ca/index_ en/ait.htm > (entered into force 1 July 1995).

6 Canada, A Framework to Improve the Social Union for Canadians: An Agreement Between the Government of Canada and the Governments of the Provinces and Territories (4 February 1999) online: Canadian Intergovernmental Conference Secretariat <http://www.scics. gc.ca/pdf/80003701_e.pdf >.

7 Richard Simeon \& David Cameron, "Intergovernmental Relations and Democracy: An Oxymoron If There Ever Was One?" in Herman Bakvis \& Grace Skogstad, eds., Canadian Federalism: Performance, Effectiveness, and Legitimacy (Don Mills, Ontario: Oxford University Press, 2002) at 279.

8 Canada, Constitutional Accord 1987 (Ottawa: Queen's Printer, 1987) [Meech Lake Accord].

9 Canada, Charlottetown Accord: Draft Legal Text (Ottawa: Queen's Printer, 1992).

10 Canadian Charter of Rights and Freedoms, Part I of the Constitution Act, 1982, being Schedule B to the Canada Act 1982 (U.K.), 1982, c. 11.

11 Peter H. Russell, Constitutional Odyssey: Can Canadians Become a Sovereign People?, 3d ed. (Toronto: University of Toronto Press, 2004) at 127-53.

12 Kathy L. Brock, "The End of Executive Federalism?” in François Rocher \& Miriam Smith, eds., New Trends in Canadian Federalism (Peterborough, ON: Broadview Press, 1995) 91.

13 Kenneth McRoberts, Misconceiving Canada: The Struggle for National Unity (Toronto: Oxford University Press, 1997) at 159-75.

14 Constitution Act, 1982, being Schedule B to the Canada Act 1982 (U.K.), 1982, c.11. See Gil Rémillard, "Legality, Legitimacy and the Supreme 
Court" in Keith Banting \& Richard Simeon, eds., And No One Cheered: Federalism, Democracy and the Constitution Act (Toronto: Methuen, 1983) 189.

15 Constitution Amendment, 1998 (Newfoundland Act) amending Newfoundland Act, 12 \& 13 Geo. VI, c. 22 (U.K.). The amendment permits NL to establish a single public school system.

16 Herman Bakvis, "Checkerboard Federalism Labour Market Development Policy in Canada" in Herman Bakvis \& Grace Skogstad, eds., Canadian Federalism: Performance, Effectiveness, and Legitimacy (Don Mills, ON: Oxford University Press, 2002) 197.

17 Martha Friendly \& Linda A. White, "From Multilateralism to Bilateralism to Unilateralism in Three Short Years: Child Care in Canadian Federalism, 2003-2006" in Herman Bakvis \& Grace Skogstad, eds., Canadian Federalism: Performance, Effectiveness, and Legitimacy, $2 \mathrm{~d}$ ed. (Don Mills, Ontario: Oxford University Press, 2008) 182.

18 Ibid. at 193.

19 Reference Re Ownership of Off Shore Mineral Rights (British Columbia), [1967] S.C.R. 792.

20 Peter H. Russell, Rainer Knopff \& F.L. Morton, Federalism and the Charter: Leading Constitutional Decisions (Don Mills, ON: Carleton University Press, 1989) 146.

21 (Ottawa: Department of Energy, Mines and Resources Canada, 1982).

22 Roger Gibbins, Conflict and Unity: An Introduction to Canadian Political Life (Toronto: Methuen, 1985) at 93.

23 Reference Re Mineral and Other Natural Resources of the Continental Shelf (1983), 145 D.L.R. (3d) 9.

24 Reference Re Continental Shelf Offshore Newfoundland, [1984] 1 S.C.R. 86.

25 Re Upper Churchill Water Rights Reversion Act, [1984] 1 S.C.R. 297.

26 1984, c.2 as rep. by Canada-Nova Scotia Offshore Petroleum Resources Accord Implementation (Nova Scotia) Act, S.N.S. 1987, c. 3.

27 "Historical Crude Oil Prices (Table)," online: $<$ http://www.inflationdata.com/inflation/Inflation_Rate/Historical_Oil_Prices_Table.asp $>$.

28 "Campaign for Fairness" launched by Premier John F. Hamm (January 2001), online: Government of Nova Scotia <http://www.gov. ns.ca/fairness/>.

\section{Ibid.}

30 Speech of the Hon. John F. Hamm, Premier of Nova Scotia (24 September 2001), online: Government of Nova Scotia <http://www.gov. ns.ca/fairness/cdnclub24_9_2001.htm>.

31 “Nova Scotia's Due," Editorial, National Post (13 June 2001) A15.

32 Alberta, Premier Klein's Mission to Eastern Canada and the United States, Final Report (Edmonton: International and Intergovernmental Relations, 2001), online: Alberta International and Intergovernmental Relations $<$ http://www. international.alberta.ca/documents/International/2001_Canada_US_Mission_Report.pdf>.

33 Newfoundland and Labrador, Royal Commission on Renewing and Strengthening our Place in Canada, 2002.

34 Royal Commission on Renewing and Strengthening our Place in Canada, Our Place in Canada (St. John's: Queen's Printer, 2003) at 155-57 [Report].

35 Ibid. at 120-21.

36 Ibid. at 122.

37 Paul Wells, "Offshore Pressure: what Newfoundland wants - and why Danny Williams may get it yet" Macleans (31 January 2005) 24, online: The Canadian Encyclopedia $<$ http://www. thecanadianencyclopedia.com/PrinterFriendly. cfm?Params=M1ARTM0012715 $>$.

38 Brian Laghi \& Campbell Clark, "Quebec formula criticized as federal cash grab" The Globe and Mail (27 September 2004) A1.

39 Brian Laghi \& Campbell Clark, "Poorer provinces plan to seek extra \$5.3-billion" The Globe and Mail (20 October 2004) A7.

40 Joan Bryden, "Ontario issues equalization warning" The Chronicle Herald (25 October 2004) A3.

41 Ibid.

42 Joan Bryden, "Ontario issues equalization warning: Province not willing to concede billions more in payments" The Globe and Mail (25 October 2004) A3.

43 Brian Laghi, "Have-not provinces grumble, but take PM's deal" The Globe and Mail (27 October 2004) A4.

44 Government of Canada, News Release, "Prime Minister Announces New Equalization and Territorial Funding Formula Framework" (26 October 2004), online: Government of Canada <http://www.scics. gc.ca/cinfo04/800043004_e.pdf>.

45 Cited in Stephen Maher, "Don't believe all you're told by the media," Editorial, The Chronicle Herald (30 October 2004) A5.

46 Jim Meek, "Oh, Danny, Boy! Williams in tune with Voice of the Common Man," Editorial, Mail-Star (30 October 2004) A13.

47 Campbell Clark, "Nfld. Liberals blast Ottawa over oil" The Globe and Mail (8 November 2004) A4. 
48 Jennifer Stewart, "Mulroney wades into offshore: Martin urged to follow ' 80 s accords, give N.S. fair share of royalties" The Chronicle Herald (10 November 2004) A1.

49 Pat Lee, "Harper: Get tough with PM: Premiers must force Martin to keep offshore 'commitment” Mail Star (10 November 2004) B2.

50 Margaret Wente, "Oh Danny Boy, pipe down," Editorial, The Globe and Mail (6 January 2005) A15.

51 "Danny Williams won't take yes for an answer," Editorial, The Globe and Mail (5 January 2005) A16. See also Christopher Dunn, "Why Williams Walked, Why Martin Balked: The Atlantic Accord Dispute in Perspective" Policy Options (February 2005) 9.

52 Stephen Maher, "N.S. guaranteed $\$ 830 \mathrm{~m}$ " The Chronicle Herald (29 January 2005). See also Canada, Arrangement Between the Government of Canada and the Government of Nova Scotia (14 February 2005), online: Department of Finance Canada <http://www.fin.gc.ca/FEDPROV05/OffshoreResAcc/novascotiaarr-e.html $>$.

53 "I want Danny Billions on my side!," Editorial, The Globe and Mail (3 February 2005) A15.

54 "If the provinces shout, Mr. Martin's all ears," Editorial, The Globe and Mail (3 February 2005) A14.

55 Gloria Galloway, "Calvert wants protection from oil, gas clawbacks" The Globe and Mail (9 February 2005) A7.

56 Brian Laghi \& Murray Campbell, "Provinces revel over offshore agreement: Equalization compromised, Ontario says, while B.C., N.B. want their own side deals" The Globe and Mail (12 February 2005) A1.

57 "McGuinty is right," Editorial, The National Post (23 April 2005) A16.

58 Karen Howlitt, "Martin's promise 'a good first step,' McGuinty says” The Globe and Mail (9 May 2005) A1.

59 Conservative Party of Canada, Stand Up for Canada (CPC, 2006) at 43.

60 Government of Newfoundland and Labrador, News Release, "The Facts About a Prime Minister's Promise" (3 April 2007), online: Government of Newfoundland and Labrador www. releases.gov.nl.ca/releases/2007/exec/0403n05. htm $>$.

$61 \mathrm{Ibid}$. The letter is dated 16 March 2004.

62 "Give equalization back its integrity," Editorial, The Globe and Mail (23 February 2006) A16.

63 Gloria Gaslloway, Brian Laghi \& Rhéal Séguin, “Quebec heaps praise on Harper's fiscal plan as Ontario rejects equalization proposal" The Globe and Mail (4 May 2006) A1.

64 Council of the Federation, Advisory Panel on Fiscal Imbalance, Reconciling the Irreconcilable: Addressing Canada's Fiscal Imbalance (Ottawa: Council of the Federation Secretariat, 2006) at 86-87.

65 Katherine Harding \& Brian Laghi, "Klein issues warning on sharing the wealth: Premier threatens to pull province out of revenue-sharing deal with Ottawa” The Globe and Mail (25 May 2006) A1.

66 Canada, Expert Panel on Equalization and Territorial Formula Financing, Achieving a National Purpose: Putting Equalization Back on Track (Ottawa: Department of Finance, 2006) online: EQTFF-PFFT < http://www.eqtff-pfft.ca/epreports/EQ_Report_e.pdf > [O'Brien Report].

67 Ibid. at 6-7.

68 Ken Boessenkool, "The premiers have missed the point on equalization," Editorial, The Globe and Mail (12 June 2006) A13.

69 Heather Scoffield, "Equalization raw deal for Ontario, experts say: Province's economy too fragile to support enriched deal, TD chief economist warns" The Globe and Mail (12 June 2006) A7.

70 Brian Laghi, "Premiers aim for consensus: Ontario agrees two-track solution needed to end squabble over equalization plan" The Globe and Mail (25 July 2006) A5.

71 Amy Smith, "It's every province for itself: Still no agreement on equalization" The Chronicle Herald (28 July 2006) A3.

72 "Rift widens between Harper, Williams: Harper does not expect premier's support, PMO statement says" CBC News (16 October 2006) online: CBC News <http://www.cbc.ca/canada/newfoundland-labrador/story/2006/10/16/harperwilliams.html>.

73 Amy Smith, "No tough talk from premier on funding: Unlike Newfoundland, MacDonald not issuing equalization ultimatums" Mail Star (17 October 2006) B1.

74 Canada, Department of Finance, Federal Transfers to Provinces and Territories: Equalization Program, online: Department of Finance <http:// www.fin.gc.ca/FEDPROV/eqpe.html>.

75 (23 March 2007) A12.

76 Michael Connors, "N.L. equalization standoff turning into civil war" CTV News (2 April 2007), online: CTV News <http://www.ctv.ca/servlet/ ArticleNews/story/CTVNews/20070402/williams_harper_070402>.

77 Jim Flaherty, "Ottawa respects Atlantic accords" Chronicle Herald (9 June 2007) A15.

78 Paul A. R. Hobson \& L. Wade Locke, "Assessing 
the Equalization Options of Budget 2007 for the Atlantic Provinces" (13 June 2007), online: Atlantic Provinces Economic Council <http://www. apec-econ.ca/pubs/\%7BF80B8A5F-8D66-48D3861E-A75EB75FC731\%7D.pdf>.

79 Gloria Galloway, "Tory MP kicked out of caucus over budget vote" The Globe and Mail (6 June 2007) A4.

80 Amy Smith, "MacDonald sick of PM's spin: Premier urging Nova Scotians to sign petition on accord" The Chronicle Herald (16 June 2007) B1.

81 Ken Boessenkool, "No Special Deals: Stick to the formula on equalization" The Globe and Mail (21 June 2007) A17.

82 "Equalization: Know a rich deal when you've got it," Editorial, The Globe and Mail (13 June 2007) A18.

83 Peter Moreira, "The economic climate is a changing" The Chronicle Herald (26 June 2007) D5.

84 John Ward, "Harper haters are here: PM's accord stance gets 9 percent support in region" The Chronicle Herald (29 June 2007) A1.

85 "Time for PM to mend fences," Editorial, The Chronicle Herald (8 August 2007) A7.

86 Canada, Panel on Crown Share Adjustment Payments, "Terms of Reference-October 10, 2007" (Ottawa: Department of Finance, 2007) online: Department of Finance <http://www.fin. gc.ca/news08/data/08-002_1e.html $>$.

87 Campbell Clark, "Williams fumes as PM reaches compromise with Nova Scotia: Newfoundland Premier blasts 'petty' PM for preying on 'weak' minority government of Rodney MacDonald" The Globe and Mail (11 October 2007) A1.

88 Stephen Maher, "Atlantic accord may not hold up to future scrutiny" The Chronicle Herald (13 October 2007) A7.

89 In the provincial election held on October 9, 2007, the Progressive Conservatives under Williams leadership won 44 of the 48 seats in the House of Assembly and 69.59 percent of the popular vote.

90 Campbell Clark, supra note 87.

91 Canada, Department of Finance, Explanatory Notes Relating to the Budget and Economic Statement Implementation Act, 2007 and Draft Regulations Relating to Tax Information Exchange Agreements (Ottawa: Department of Finance, 2007) online: Department of Finance $<\mathrm{http}: / /$ www.fin.gc.ca/drleg/DregNov07_e.html>.

92 Tara Brautigam, "Williams to Harper: It'll cost $\$ 10 \mathrm{~b}$ to end feud" The Chronicle Herald (1 December 2007) A4.

93 Oliver Moore, "Nfld. Sets record \$882-million surplus: Most of the revenue from high oil and nickel prices will go to paying down debt, Finance Minister says" The Globe and Mail (11 December 2007) A6.

94 Amy Smith, "Atlantic premiers meet today: Williams, MacDonald share common equalization ground" The Chronicle Herald (12 December 2007) B2.

95 Government of Newfoundland and Labrador, News Release, "Newfoundland and Labrador Has Not 'Signed Onto' Any Equalization Deal” (12 December 2007), online: Government of Newfoundland and Labrador $<\mathrm{http}: / / \mathrm{www}$.releases. gov.nl.ca/releases/2007/exec/1212n06.htm>.

96 Government of Newfoundland and Labrador, News Release, "Minister Provides Update on 2007-08 Equalization Election” (16 April 2008), online: Government of Newfoundland and Labrador $<$ http://www.releases.gov.nl.ca/releases/2008/fin/0416n08.htm>.

97 See Karen Howlett, "Ontario at risk of mild recession, TD report says" The Globe and Mail (21 March 2008) A5; Heather Scoffield, "Ontario risks losing 'fat cat' status: National economic clout fades as trade slows with United States" The Globe and Mail (26 March 2008) B1; and Karen Howlett \& Heather Scoffield, "From powerhouse to poor cousin: Canada's once-mighty economic engine could slip to have-not status within two years, a report predicts" The Globe and Mail (30 April 2008) A4.

98 Neil Reynolds, "Equalization payments equal unfairness" The Globe and Mail (20 February 2008)

B2.

99 Ontario will receive \$337 million in equalization entitlements in 2009-10. See Lee Greenberg, "Ontario officially a 'have-not,' to get \$337M in equalization" Ottawa Citzen (4 Nov 2008) A1.

100 Stephen Maher, "Accord deal's value shrinking? Expert: N.S. share will be 'a lot smaller' if Ontario becomes have not province" The Chronicle Herald (6 May 2008) A1. 